\title{
Remittance Income in Nepal: Need for Economic Development
}

\author{
Yadav Sharma Gaudel
}

\begin{abstract}
Remittance as a major source of foreign currency to the developing nation has become a substantial component of making current account surplus in the balance of payments. It is argued that many workers from Nepal going abroad for employment are no doubt young, energetic, laborious and enthusiastic. They do hard work for earning large remittance income to support their families. However, the downside of remittances reflects the view that remaining young generation for long time outside without family may increase their vulnerability and ultimately they will have a tendency to leave their homeland. Thus, in order to recover the loss of economically active labor force to the domestic economy, they should be encouraged to come back again with skilled knowledge for utilizing their savings and working experience for development to the productive areas in accordance with the priority of the national development plans.
\end{abstract}

Key words: remittance, developing countries,

REMITTANCE INCOME IN DEVELOPING countries has become a lifeline for economic development. By remittance we mean sending income in terms of money or goods in home by the migrants or workers who have their earnings outside their home country. Now-adays, this source of foreign income has been growing rapidly in each year in developing countries. Since long time in Nepal, many migrants have been transferring their income through the unofficial channels. Today due to the establishment of different agencies like Western Union, International Money Express (IME) etc. in several district headquarters of the country, the remittance flows has become popular for transferring cash or money in time to the recipients. However, it is difficult to calculate the exact size of remittance flows in Nepal due to the emergence of unofficial channels even though it has recorded in balance of payments account. In this regard, it is estimated that unrecorded flows through informal channels are believed to be more than 50 percent of the recorded flows in developing countries (Ratha 2005).

Remittances are especially important for low-income countries. A remittance transaction is completed in three steps. In the first step, the sender pays the remittance to the sending agent or institution using cash, cheque or money order or a debit card using ecommerce and so on. In step second, the sending agency instructs its agent in the recipients' country to deliver the remittance. In the third step, the paying agent or union operator makes the payments to the beneficiary. Formal remittances are periodically followed between sending agents and paying agents according to their agreed schedules. However, informal remittances are settled particularly through goods trade. This scheme of sending money has played an important role to deliver money transfer services in a convenient way. The cost of remittance transaction includes a fee charged by the sending agent, which is paid by the sender and a currency conversion fee for delivery of local currency to the beneficiary in recipient country. In such a transaction, money transfer operators require the beneficiary to pay a fee to collect remittances. This fee may be charged to account for frequent exchange rate movements. Moreover, if this remittance comes through commercial banks or financial institu- 
tions, they may earn an indirect fee in the form of interest by investing funds before delivering the amount to the beneficiary.

\section{Significance of Remittances}

Remittances are typically helpful to meet specific needs of the respondents' family members and thus tend to increase their standard of living. In lower class or poor households, they may finance their remittances to fulfill their basic needs, such as in consumption, housing, children education and health care and to pay for loan. In middle class or rich households, they may provide either loan for individuals going abroad or capital for businesses and entrepreneurial activities. From macro economic point of view, this source may be more stable than capital flows. It is said that remittances has represented more than 10 percent of GDP in Nepal in the late 1990s. Moreover, it would be highly beneficial to the country, where there is natural calamities, political conflict, people war, low investment in entrepreneurial activities and economic recession.

Minimizing transaction costs would significantly help recipients' families. The cost of remittance service does not really depend on the amount of principal. Indeed, the real cost of a remittance transaction include labor charges, house rent, technology, networks etc. It is also known that greater competition among banks and money transfer operators (MTO) brings down the cost of transaction. Furthermore, remittance fees can be reduced significantly if they were converted to a flat fee instead of a percentage of the principal transferred (Ratha 2005). In addition, some commercial banks have recently started providing remittance services than money transfer operators. Both sending and receiving countries can increase banking access for migrants by facilitating participation of financial institutions and credit unions in the remittance market. Keeping these facts into consideration, this paper has raised some issues regarding the flow of remittance income and its role in economic development of Nepal. The basic issues are: How is money transferred under the process of remittances? Why are remittances helpful for economic development? How these sources of finance are utilized? What is the relationship between remittances and GDP? What are their socio-economic implications? With these issues, this paper has set some specific objectives.

\section{Objectives}

The specific objectives are:

i) To describe the role of remittance income for economic development of Nepal.

ii) To analyze the socio-economic implications of remittances in Nepal.

iii) To compare the relationship between remittance income and foreign direct investment in Nepal.

iv) To measure the statistical relationship of GDP among workers' remittances, grants and pensions in Nepal

\section{Remittances and Economic Growth}

There are a number of potential costs associated with remittances. If remittances are large, the recipient country could face an appreciation of the real exchange rate that may make its economy less competitive internationally. In this regard, some argue that remit- 
tance can also create dependency, reduction in recipients' incentives to work and thus slowing economic growth. But others argue that remittance may also have human costs. Migrants sometimes make significant sacrifices, family separation and incur risks to find works in another country. Consequently, they may have to work hard for saving enough to send remittances.

Basically, remittances are private funds that should be treated like other sources of households' income. In terms of asset formation, larger number of remittance receivers uses their funds to purchase land or buildings in town areas. Someone purchase means of transportation as a part of their investment. Very rare is found in promoting agriculture and tourism. In short, it could be asserted that the productive use of remittance income is yet to be sought though it forms a significant part of GNP. Furthermore, in order to channel remittances in productive areas for economic growth, the government should offer incentive to increase remittance flows. Tax incentives like rebates or concession may attract remittances, but they may also encourage tax evasion. The government has to assess prospective growth rates, potential for exports, revenue elasticity and composition of existing debt. Besides, the government may choose to increase either external borrowing or to raise remittances for economic growth (Heller 2005).

If we observe the economic growth rates of some SAARC countries in 2006, we find the highest growth rate ( 8.2 percent) of India and the lowest growth rate (1.9 percent) of Nepal. Sri Lanka has received the second position ( 7.0 percent) then Bangladesh (6.7 percent) and Pakistan (6.6 percent)(Annapurna Post, Dec.15, 2006). In such a circumstances, Nepal has reached the insignificant growth rate because of prevalence of the political conflict, unfavorable climate for agriculture and reduction in export of readymade garments. However, Bangladesh has received the third position in economic growth rate mainly by increasing the flow of remittances and maintaining strong production sector. Thus, remittance as a major source of foreign exchange earnings can improve a country's creditworthiness and enhance its access to international capital markets

\section{Remittance Income in Nepal}

Initially, remittance in Nepal was introduced with Gurkha remittances. 'The Gurkhas' were renowned for good qualities of soldiers. That is why British India formally recruited Nepalese youth as a regular army, which later divided into British and Indian army. Now-adays, Nepalese going abroad are not only for armies but also spread all over the world for work and mostly they are concentrated in Gulf areas in civilian front (Kshetry 2003). Any Nepali to go for work legally, he/she needs to get permission from the Department of Labor under the Ministry of Labor and Transport of the Government of Nepal. From the official report of the Labor Department it is known that 107 countries are at the government list where Nepalese are allowed to go for work (Annex B). But still some people are found going abroad without permission and working in the government restricted areas too. Because of this trend, data on foreign employed workers are not available in exact form. Majority of those who have left home for overseas job are eager to earn foreign currency by hard working to support their families.

With regard to the delivery of remittances, the World Bank has expressed the view that the procedure of receiving remittance in Nepal is the best one in compare to others. 
Remittance Transaction Company cannot receive cash directly from the Nepalese workers remaining outside. The workers have to deposit their remittances in foreign commercial banks account and the transaction company through its account delivers the remittance services to the recipients at the cheapest cost (about 1 percent of remittance income)(Annapurna Post, March 15,2005). Moreover, the Hundi system is almost closed due to the establishment of Remittance Company in Malaysian and Gulf countries. However, the system of Hundi is still working in Japan and Korea where most Nepali workers are living even if their visa date is expired.

Over the past 15 years from 1991, international migrants' remittances have become increasingly prominent in our country. The amount of remittances reflects only transfer record in the balance of payments. Unrecorded flows through informal channels are believed to be more than the recorded flows. Regarding the transfer of remittances in Nepal, the record of banking sector showed that Rs.15.9 billion was received in FY.2000/01. However, Hundi operators or money transferring agencies handled the bulk part of remittances. Considering the increasing number of workers, assuming four lakh per year going outside the country in this perspective, remittance received was estimated at Rs.50 billon in FY. 2001/02, (Kshetry 2003). In this regard, it is also estimated that more than 500 people per day are going abroad for foreign employment. From such migrants, about Rs.100 billion per year is expected to enter into the country through remittance income only (Annapurna Post, Oct.28, 2006). In order to provide access for transferring remittances, Western Union, IME and Prabhu Money Transfers are found active in Nepal. Of these agencies, more than 200 sub-agents of single Hulas remittance including banks, finance companies, trading concerns, enterprises etc. under the province of Western Union, have been opened in five Development Regions of Nepal. These agents deliver remittances to the recipients of local areas within a short span of time.

\section{Contribution of Remittance to GNP}

Remittance as major component of current account ${ }^{1}$ plays a vital role in increasing current transfers in balance of payments. The basic factors of determining current transfers are grants, workers remittances, pensions and others including excise refund also. This is clear from Table 1

Initially, the share of remittance to GNP was found 1.74 percent in mid-July 1991.This share increased sharply (9.38 percent) after the period of mid-July 1999 and eventually reached to 12.03 percent in mid-July 2005. On average, the share of remittance to GNP was 11.03 percent during the review period from mid-July 2000 to 2005. Under the transfer category of BOP, remittance income increased by 11.65 percent totaling Rs. 65.42 billion in 2005 due to the increasing trend of Nepali workers going to Malaysia and Gulf countries for employment (MOF 2006). During that period, the grants and pension also increased by 7.72 percent and 58.06 percent respectively. Thus, from this analysis it is clear that the remittance income has become an important contributor (64.72 percent) to the current transfers in balance of payments of Nepal

\footnotetext{
${ }^{1}$ Current account consists of services net, income net and transfer net in BOP.
} 
Table: 1 Share of Remittance to GNP

(Rs. in Million)

\begin{tabular}{lccccccc}
\hline $\begin{array}{c}\text { Year } \\
\text { Mid-July }\end{array}$ & Grants & $\begin{array}{c}\text { Workers' } \\
\text { Remittance }\end{array}$ & Pensions & Others & Total & $\begin{array}{c}\text { GNP at } \\
\text { Current } \\
\text { Price }\end{array}$ & $\begin{array}{c}\text { Share of } \\
\text { Remittance } \\
\text { to GNP }\end{array}$ \\
\hline 2000 & 12874.8 & 36818.1 & 5941.0 & 1318.9 & 56952.8 & 392613 & 9.38 \\
2001 & 12046.4 & 47216.1 & 6309.1 & 1456.1 & 67027.7 & 427447 & 11.05 \\
2002 & 12650.5 & 47536.3 & 8269.6 & 1700.9 & 70157.3 & 441182 & 10.77 \\
2003 & 13842.2 & 54203.3 & 7327.3 & 2392.3 & 77765.1 & 472869 & 11.46 \\
2004 & 19557.8 & 58587.6 & 7906.2 & 3110.2 & 89161.8 & 509700 & 11.49 \\
2005 & 21067.2 & 65416.0 & 12496.4 & 2104.8 & 101084.4 & 543902 & 12.03 \\
\hline
\end{tabular}

Sources: Economic Survey (various issues), Ministry of Finance, Government of Nepal.

Main Economic Indicators (May-July), 2005, Monthly Report, NRB: Research Department, Kathmandu.

\section{Socio-Economic Implications of Remittances}

The income of migrants from the foreign employment has not only increased their personal income but also their social prestige. The rural people lying below the poverty level have succeeded to uplift their economic standard receiving the opportunity of foreign employment. Moreover, the downside of remittance reflects the view that the shortage of labor due to emigration has not only compelled to keep barren land in rural areas but also hamper agricultural productivity and ultimately the country would be liable to import the large quantity of food grains.

Despite these, remaining young generation from the families for long time may affect their reproductive age and their vulnerability may be subject to communicable diseases. It is also possible that if they come back with good skills and earnings, they may not normally cope with the environment of the homeland and consequently they will have a tendency to leave the country again. Thus, the remittances from foreign employment on the one hand, has played an important role to increase their personal income and thereby improve standard of living and a risk of diseases like HIV/AIDS through migrants on the other may enter into the country. More specifically, this type of communicable disease may be due to poverty, illiteracy, gender discrimination, women exploitation, insecurity, and the lack of legal advice as well as proper treatment. Thus, to minimize this problem, especially rural people should be made aware of the communicable diseases through mass media, education, health care and training cum workshops. Furthermore, a part of remittance income should set aside by the government through welfare scheme that may become the long run solution to the problem of communicable diseases.

Recently, the decision made by British government has provided the permission for the permanent residence in U.K. to the ex-army of Nepal retired before 1997. From this decision, remittance as a major source of the Nepalese economy will have negative impact in the long run.

\section{Comparisons of Remittances and Foreign Direct Investment}

Over the past ten years, emigrant remittances have become prominent exceeding Rs.65 billion in FY. 2004/05. This analysis of ten years (FY. 1995/96 to FY. 2004/05) has 
recorded that remittances are the major sources of financing compared to the foreign direct investment. This will be clear from Table 2 and Fig.1.

Table: 2 Comparisons of Remittances and Foreign Direct Investment

\begin{tabular}{ccc} 
& & (Rs. in Billion) \\
\hline Fiscal Year & Foreign Direct Investment & Workers' Remittances \\
\hline $1995 / 96$ & 0.39 & 4.28 \\
$1998 / 99$ & 0.58 & 10.31 \\
$2002 / 03$ & 0.96 & 54.2 \\
$2004 / 05$ & 0.14 & 65.42 \\
\hline
\end{tabular}

Source: Government of Nepal, Economic Survey (various issues).

Fig. 1: Remittances and Foreign Direct Investment in $\mathrm{Ner}$

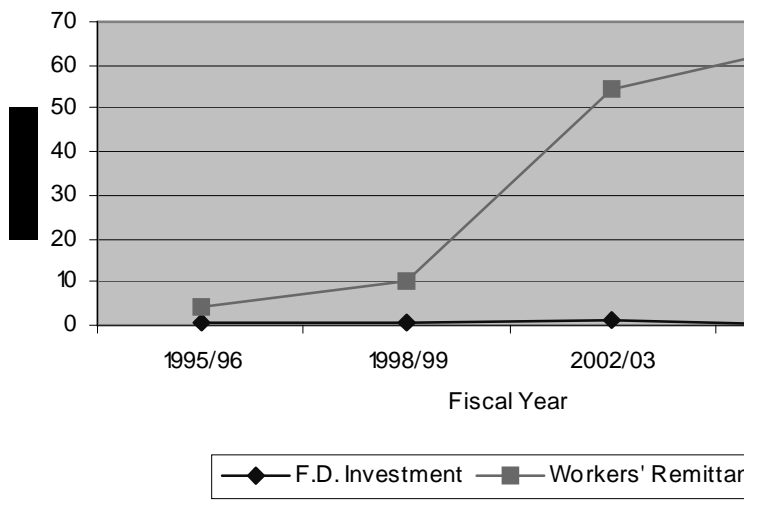

\section{Regression Results and Economic Interpretation}

Table: 3 Regression Results

\begin{tabular}{|c|c|c|c|c|c|c|}
\hline \multirow[t]{2}{*}{$\mathbf{E q}^{\mathrm{n}}$} & \multirow{2}{*}{$\begin{array}{l}\text { Depend. } \\
\text { Variable }\end{array}$} & \multirow[t]{2}{*}{ Independent Variables } & \multicolumn{3}{|c|}{ Statistic } & \multirow[b]{2}{*}{ DW } \\
\hline & & & $\mathbf{R}^{2}$ & Adj. $R^{2}$ & $\mathbf{F}$ & \\
\hline 1 & GDP & $\begin{array}{l}202374.3+5.174 \mathrm{Rem} \\
(11.109) * * * * 9.493)^{* * *}\end{array}$ & .874 & .864 & $90.1 * * *$ & 0.459 \\
\hline 2. & GDP & $\begin{array}{l}133463.2+2.138 \mathrm{Rem}+14.302 \mathrm{Gr} \\
(10.029) * * *(4.144) * * *(6.793) * * *\end{array}$ & .974 & .970 & $224.6 * * *$ & 1.166 \\
\hline 3. & GDP & $\begin{array}{l}132492.5+15.431 \mathrm{Gr}+8.972 \mathrm{PO} \\
(8.184)^{* * *}(6.160)^{* * *}(2.960)^{* *}\end{array}$ & .963 & .957 & $158.1 * * *$ & 1.218 \\
\hline
\end{tabular}

Source: Annex (A)

$G D P=$ Gross Domestic Product, Rem=Remittances, Gr=Grants, $P O=$ Pensions \& Others

Note: Figures in parenthesis are t values, * denotes $10 \%$ level of significance, $* *$ denotes $5 \%$ level of significance, $* * *$ denotes $1 \%$ level of significance. 
$\mathrm{R}^{2}=$ degree of explanation of the dependent variable

Adj. $R^{2}=$ Proportion of variation adjusted to the degrees of freedom

$\mathrm{F}=\mathrm{F}$ statistic for the joint significance of all coefficients

DW= Durbin-Watson statistics for the presence of autocorrelation.

As shown in Table 3, the coefficient of remittances in equations 1 and 2 indicates that 1 percent change in remittance income will increase GDP by 2.13 percent to 5.17 percent respectively. In the same way, the coefficient of grants is found to be large in both equations. It implies that 1 percent increase in grants increases GDP by 14.3 percent to 15.4 percent in equations 2 and 3 respectively. An examination of t-values associated with the different coefficients reveals that the remittance income in both equations (1 and 2) is highly significant at 1 percent level. It means that remittance income variable is more responsible to increase GDP in the nation. Apart from this, the coefficient of grants in both models (2 and 3 ) is highly significant at 1 percent level. It shows that grants are more effective to increase GDP in the economy. In the same way, pension and other items are also found to be effective to raise GDP in the country.

From the test statistic, it is apparent that all regression models are highly significant at 1 percent level as indicated by the size of $\mathrm{F}$ statistic. The percentage of variation explained by $\mathrm{R}^{2}$ and adj. $\mathrm{R}^{2}$ produces better results indicating the range from 0.864 to 0.974 . However, the Durbin-Watson statistic for all regressions are found very low with large constant coefficients and standard errors of estimation. More specifically, DW statistic in equation 1 lies below the lower limit of critical value (1.08) and supports the hypothesis of positive serial correlation. But in the other two equations (2 and 3), DW falls in the zone of indecision and tends to suggest for other new tests of autocorrelation. Thus, a summary of the results obtained from regression models leads the following major findings.

- Remittance income and Grants appear to be the most relevant variables to raise nominal GDP in Nepal

- Pension and other items have also significant impact on increasing nominal GDP in Nepal.

\section{Conclusion}

From the foregoing analysis, it can be concluded that remittances and grants are claimed as an important sources of increasing foreign exchange earnings in Nepal. Moreover, remittances may be a dependable source of national income for economic development if there is job guarantee for the workers with the wage level equivalent to the residence of the foreign country. Furthermore, the young and energetic generation remaining outside should be attracted to come back again with skilled knowledge and experience and to provide the way for utilizing their remittances in productive sector. Thus, remittance received so far taken by the country is considered as boon, and the government should pay attention to make workers confidence to deal with whatever anomalies arise in working places. Besides, the policy of providing permanent residence in outside for retired workers should be amended to continue the source of increasing remittance flow in Nepal. 
Annex A: Remittance, Grants and Nominal GDP

\begin{tabular}{crccc}
\hline $\begin{array}{c}\text { Year } \\
\text { Mid-July }\end{array}$ & Grants & W/Remittance & $\begin{array}{c}\text { Pensions \& } \\
\text { Others }\end{array}$ & Nominal GDP \\
\hline 1991 & 1694.00 & 2128.30 & 218.20 & 122517.0 \\
1992 & 1689.50 & 2316.50 & 483.90 & 152202.0 \\
1993 & 3498.50 & 2994.30 & 582.70 & 174705.0 \\
1994 & 3039.90 & 3469.10 & 494.90 & 203135.0 \\
1995 & 5339.10 & 5063.60 & 824.50 & 223992.0 \\
1996 & 7582.80 & 4283.60 & 899.90 & 252479.0 \\
1997 & 9743.20 & 5595.00 & 1009.10 & 285173.0 \\
1998 & 10919.70 & 6987.80 & 1157.80 & 306870.0 \\
1999 & 11648.30 & 10314.60 & 1204.60 & 352917.0 \\
2000 & 12874.80 & 36818.10 & 7259.90 & 392613.0 \\
2001 & 12046.40 & 47216.10 & 7765.20 & 427447.0 \\
2002 & 12650.50 & 47536.30 & 9970.50 & 441182.0 \\
2003 & 13842.20 & 54203.30 & 9719.60 & 472869.0 \\
2004 & 19557.80 & 58587.60 & 11016.40 & 509700.0 \\
2005 & 21067.20 & 65416.00 & 14601.20 & 543902.0 \\
\hline
\end{tabular}

Sources: Economic Survey (various issues), Ministry of Finance, Government of Nepal. Main Economic Indicators (May-July), 2005, Monthly Report, NRB, Research Department, Kathmandu.

\section{Annex B: List of Countries Opened for Foreign Employment}

Government of Nepal has formally opened the following 107 countries on institutional basis for sending laborers in foreign employment. But now-a days, the government has also restricted to go Nepali workers in some foreign countries including Iraq* due to massacre of 12 Nepali laborers in Iraq.

\begin{tabular}{|c|c|c|c|c|c|c|}
\hline S.N. & Country & S.N. & Country & S.N. Country & S.N. & Country \\
\hline 1 & France & 28 & Belgium & 55 Iceland & 82 & Ireland \\
\hline 2 & China & 29 & Iran & 56 Holy see $^{1}$ & 83 & Bosnia Herzegovina \\
\hline 3 & Russia & 30 & Canada & 57 Malta & 84 & United Arab Emirates \\
\hline 4 & Japan & 31 & Denmark & 58 Panama & 85 & Qatar \\
\hline 5 & Sri Lanka & 32 & Bulgaria & 59 Tunisia & 86 & Saudi Arabia \\
\hline 6 & Egypt & 33 & Romania & 60 Fiji & 87 & Kuwait \\
\hline 7 & Germany & 34 & Algeria & 61 Zambia & 88 & Iraq* \\
\hline 8 & Austria & 35 & Spain & 62 Mozambique & 89 & Bahrain \\
\hline 9 & Italy & 36 & Bangladesh & 63 Nicaragua & 90 & Oman \\
\hline 10 & Switzerland & 37 & Albania & 64 Venezuela & 91 & Hong Kong \\
\hline 11 & Poland & 38 & Norway & 65 Colombia & 92 & Malaysia \\
\hline 12 & Greece & 39 & Finland & 66 Bolivia & 93 & Singapore \\
\hline 13 & Philippines & 40 & Tanzania & 67 Estonia & 94 & Brunei \\
\hline 14 & Australia & 41 & Morocco & 68 Ukraine & 95 & South Korea \\
\hline 15 & Myanmar & 42 & Cuba & 69 Armenia & 96 & Saipan $^{4}$ \\
\hline 16 & Pakistan & 43 & Cambodia & 70 Kazakhstan & 97 & Kosovo $^{5}$ \\
\hline 17 & Netherlands & 44 & Vietnam & 71 Byelorussia & 98 & Latvia \\
\hline 18 & Laos & 45 & Kenya & 72 Moldavia & 99 & South Africa \\
\hline
\end{tabular}




\section{Annex B (Continued)}

\begin{tabular}{|c|c|c|c|c|c|c|}
\hline 19 & Sweden & 46 & Mexico & 73 & Czech Republic & 100 Israel \\
\hline 20 & Thailand & 47 & Luxembourg & 74 & Republic Slovakia & 101 Macao \\
\hline 21 & Indonesia & 48 & Nigeria & 75 & Guyana & 102 United States of America \\
\hline 22 & Mongolia & 49 & Libya & 76 & South-West Africa & 103 United Kingdom \\
\hline 23 & Hungary & 50 & Peru & 77 & Azerbaijan & 104 Afghanistan \\
\hline 24 & Chile & 51 & Brazil & 78 & Seychelles ${ }^{3}$ & 105 Cyprus \\
\hline 25 & Argentina & 52 & Portugal & 79 & Slovenia & 106 Jordan \\
\hline 26 & Turkey & 53 & Costa Rica & 80 & Macedonia & 107 Sechelles $^{6}$ \\
\hline 27 & Lebanon & 54 & Mauritius & 81 & Croatia & \\
\hline
\end{tabular}

Source: Labor Market Information Bulletin, Year 4(11), Annual Publication, 2062,P.28

Website: www.moltm.gov.np

1.Vatican City, Italy.2.South-West Africa-Namibia.3.Island country in the Western Indian Ocean, north of Madagascar.4. Island of Western Pacific Ocean. 5.Region of Southern Serbia.6.North African Island-It was changed from Seychelles in 1756 in honor of French Minister of Finance.

\section{REFERENCES}

Nepal Government, Ministry of Finance (MOF). 2006. Economic Survey, FY.2005/06.

Kathmandu: Ministry of Finance.

Heller, P. 2005. Fiscal Space: What It Is and How to Get It? Finance and Development 42 : 32-33.

Kshetry, D.B. 2003. Remittances: Costs and Benefits. Nepal Rastra Bank Samachar $48: 9-12$.

Nepal Rastra Bank. 2005. Main Economic Indicators (May-July), Monthly Report, NRB, Research Department, Kathmandu.

Ratha, D. 2005. Remittances: A Lifeline for Development. Finance and Development 42: 42-45. 